\title{
Analysis of the Relationship of Late Payment Customers' Characteristics Based on Payment Bills
}

\author{
Diah Oktavia $^{1}$, Joko Lianto Buliali ${ }^{2}$, and Sutikno ${ }^{3}$
}

\begin{abstract}
An increase number of internet usage has an influence on service operators to be able to provide a variety of services (multi services) and improve internet network technology for their customers. One of them is an Internet Service Provider (ISP) company. The customer's obligation is to pay bills on time in accordance with company's terms and conditions agreed upon at the beginning of the internet installation. However, late payments still occur at least once a year. This affects the company's business processes and finances. While on the customer side, this causes internet isolation.
\end{abstract}

The purpose of this study is to analyze any variables that have a relationship with the late payment based on customer bills. The analytical method used was the Chi-Square test. The number of samples used was 400 customers with purposive sampling technique. In addition, an analysis of the pattern of customer characteristics in bill payments was done to determine whether there was a dependency based on regional mapping in Surabaya using the Morans'I and LISA Cluster Map indexes. The result showed that there was a significant relationship between address, income level, employment status, and payment period with payment status. There was no significant relationship between customer type, subscription package, and educational level with payment status. In addition, it is known that customers tend to make payments above the agreed time period. The mapping results by region showed that there were customer patterns that were clustered and having similar characteristics in adjacent locations. Autocorrelation showed positive dependencies of total income and employment status variables.

Keywords-Chi-Square, Internet Service Provider, late payment, LISA, Moran's I.

\section{INTRODUCTION}

Along with the changing millennial lifestyle, people need access to diverse, easy, fast and reliable information. The rapid development of network access technology and internet-based technology makes it possible for service operators to be able to provide a variety of services (multiservice) for their customers. This is an opportunity as well as a challenge for telecommunications service operators.

Based on Act Article 5 Number 8 of 1999 concerning Consumer Protection, among the four obligations of to

${ }^{1}$ Diah Oktavia is with Department of Management Technology, Institut Teknologi Sepuluh Nopember, Surabaya, Indonesia. Email: diahokta1210@gmail.com.

${ }^{2}$ Joko Lianto is with Informatics Department, Institut Teknologi Sepuluh Nopember, Surabaya, Indonesia. Email: joko@its-sby.edu2.

${ }^{3}$ Sutikno are with Statistics Department, Institut Teknologi Sepuluh Nopember, Surabaya, Indonesia. Email: sutikno@ statistika.its.ac.id. meet the community's needs. One of the telecommunication company's service products offered and widely used by the public and companies is the ISP (Internet Service Provider) service. Consumers are having good intention in carrying out purchases of goods and/or services and paying according to the agreed exchange rate. The intended statement is timely in accordance with the agreement at the beginning of purchasing. However, there are still a number of late payments in the last one year. This is recorded in the company's payment collections data. The data is calculated based on a bill per customer (1 internet number) multiplied by 12 times of payment in one year (12 months). In the actual business process, the bill payment must be paid on the 1st to the 20th day of the $\mathrm{N}$ month. Customers who are late in paying their bill will be fined.

Claims or receivables are claims submitted to customers in the form of money, goods or services[1]. In the operational process of service management, the late payment has a negative impact on both the company and the customer. Customer convenience can be disrupted due to isolation carried out for all types of services. Whereas according to Luo and Homburg[2], Total Quality Service can be explained as a means and infrastructure to achieve customer satisfaction and bonding. Good service quality can lead to consumer loyalty and even attract new consumers. This is because consumers are satisfied with their needs, thus the company will get long-term benefits[3]. While the impact for the company as a service manager according to Muslich is risks that may occur in receivable are irregular cash flows and unfulfilled financial targets.

Previous research on late payment by Wijayanti[4] was titled "Analysis of Factors Affecting Micro Business Credit Arrears in Kramat Jati Swamitra Koppas". In the study using Chi-Square analysis and multiple linear regression from the results of distributing questionnaires to credit debtors. The purpose of the study was to analyze the factors that influence micro-business credit arrears in both positive and negative relationships. However, the variables tested were different from the variables to be tested in this study. In addition, previous research related to Morans'I mapping was also conducted by Xiao-Ni Huo et.al.[5] under the title Combining Geostatistics with Moran's I Analysis for Heavy Metals Mapping Soil in Beijing, China. The aim of the study was to map the spatial distribution of heavy metals in potential environmental pollution risk assessments and to establish protocols for pollution improvement, in particular, for China. The difference that 
will be made in this research is mapping the distribution of customers in each region of Surabaya.

There are several variables as hypothesis basis on research regarding late payment. These variables include address (H1), customer type (H2), educational level (H3), total income (H4), employment status (H5), payment period (H6), subscription package (H7), and payment status. A purpose of testing the hypothesis is to provide a framework for reporting the conclusions of the investigation[6]. In this study, the analysis would be conducted using Chi-Square statistical tests to see how the relationship among the hypothesis testing variables. Furthermore, weighting with one of the spatial weighting matrices was done to find out the relationship of dependencies between the angles and sides of one region with the neighboring regions using the Moran's I test and the LISA index. The results of the statistical test of hypothesis would be presented in the form of descriptive quantitative analysis, while the weighting of the spatial matrix would be presented in the form of customer distribution mapping using ArcGIS tools based on the address of the villages.

Based on the problem description above, this study aims to determine the distribution of customer who tends to do a late and timely payment in Surabaya. The dependency analysis that would be carried out was by weighting the spatial matrix at the village locations that are intersected. The end result is the proof of the hypothesis of each variable that is related to late payment. In addition, the customer distribution mapping was illustrated to determine the patterns and characteristics of payments in each region of Surabaya. It is expected that the results of this study can be used as a reference to provide managerial marketing strategies in managing customers that tend to do late payment, choosing appropriate customer targets and increasing upselling.

\section{LiterATURE REVIEW}

\section{A. Late Payment Theory}

Late payments can be interpreted as not meeting the planned payment term with the actual conditions of payment or it can be said as late payment period in accordance with the payment rules in the contract agreed upon by both parties. Late payment of a project will result in negative company's cash flow[7]. The payment period is an important factor that affects the performance of the company[8]. When profitability is limited, management becomes vital and better collection procedures could help increasing profitability.

\section{B. Theoretical Framework}

Based on the identification of factors that suspected to have an association with late payment, it will form a formulation of the research hypothesis. The research hypothesis is a temporary answer to the research questions. The research hypothesis is formed from variables in the payment collection data. The formulation of the research hypothesis will be explained as follows:

\section{1) Address}

Based on the research of Sugiarto and Tjahjorini (2006) related to the problem of street children, they stated that a dense/overcrowded residence can lead to various problems that influence the growth process and behavior of street children. The definition of social class in Engel et al[9] is the grouping of people who has the same behavior based on their economic position in the market where class membership exists and can be described as a statistical category. While the status group reflects a community's expectation of lifestyle among each class as well as positive and negative social estimation of the honor given by each class.

$\left(H_{1}\right)$ : Is there a significant relationship between address and late payment?

\section{2) Customer Type}

In this study, the customer type in the data payment collections is the type of occupancy. According to Salama[10] and Listyorini[11] lifestyle factors are one of factors that greatly influence customer decisions in buying a home. In a study conducted by Salama (2006) it was found that human lifestyle influenced the choice of home location, visual appearance of the house, and the level of satisfaction. The type of customer based on occupancy type consists of residential type (housing / landed house / boarding house / rented house), premium cluster (luxury apartment / housing), and government / service / TNI / POLRI housing.

$\left(H_{2}\right)$ : Is there a significant relationship between customer type and late payment?

\section{3) Educational Level}

According to Law Number 20 of 2003, education is a conscious and planned effort to create a learning atmosphere and learning process to make students actively develop their potential to have religious spiritual strength, self-control, personality, intelligence, noble character, and the necessary skills needed by him, society, nation and country. Education affects customers in making decisions, customers with high education have different views on alternative brands and prices compared to lower educated customers. According to Law No. 2 of 1989, the educational level which includes the school education pathway consists of: basic education, secondary education, higher education and not in school or have not been in school.

$\left(H_{3}\right)$ : Is there a significant relationship between educational level and late payment?

\section{4) Total Income}

Income is a result received by a person or household from business or work[12]. Income is the total earnings received from both the formal and non-formal sectors which are calculated in a certain period of time. Central 
Bureau of Statistics specifies income in the following categories:

1) Income in the form of money is any earnings in the form of regular money that is usually accepted as a reward or achievement, the source comes from:

a) Salaries and wages received from basic salary, side work, overtime and seasonal work.

b) Personal business which includes net revenue from personal business, commissions, sales and home crafts.

c) Investment return is income earned from land rights. Serial advantage is income earned from ownership rights.

2) Income in the form of goods is payment of wages and salaries determined in rice, medicine, transportation, housing and creations.

$\left(H_{4}\right)$ : Is there a significant relationship between total income and late payment?

\section{5) Employment Status}

Employment from a legal standpoint is actions or activities carried out continuously, openly based on certain qualities, with the aim of earning income (Suwardi, 2015:23). Employment in the broadest sense is the main activity carried out by humans, in the narrow sense the term employment is used for a task/work that generates money for someone. Employment is divided into four, namely unemployed, Housewives, Civil Servants (PNS), and Entrepreneurs. Whereas according to the Central Buerau of Statistics, employment status is position type of a person in performing a business unit or activity.

$\left(H_{5}\right)$ : Is there a significant relationship between employment status and late payment?

\section{6) Payment Period}

Mowen[13] stated that buying interest is the tendency of consumers to buy a brand or take actions related to purchasing that is measured by possibility level of purchasing. Another opinion said that buying interest is something related to consumer's plans to buy a certain product and the number of products needed in a certain period (Sutisna and Pawitra, 2001). Customer satisfaction is highly correlated with the intention to repurchase in the future. In the initial period of purchase (the period before consumption) is a function of the previous attitude coupled with satisfaction in the next period (period after consumption). Research on customer behavior also concluded that customer decisions are still taken by the concerned person even though there is involvement/influence from outside. If a customer has a high level of loyalty, then in certain periods they will still prioritize a service bill even though the consumption level is high

$\left(H_{6}\right)$ : Is there a significant relationship between payment period status and late payment?

\section{7) Subscription package}

Ritawati Tedjakusuma, Sri Hartini and Muryani (2001) concluded that customer behavior is influenced jointly and meaningfully by education, income, price, quality, distribution and promotion factors. Kifli Nur (2002) indicated that there is one important attribute in purchasing decisions, namely price attributes, in addition to other important attributes such as reputation, honesty, and location attributes. This conforms the theory of Engel et al.[9] in frequent transactions, customer behavior is determined, or rather forced by available resources to be exchanged for goods or services sold by an organization. Therefore, marketers has to understand about customer resources including money, time and customer attention as a main resource besides other resources

$\left(H_{7}\right)$ : Is there a significant relationship between subscription package status and late payment?

\section{Chi-Square Method}

Chi Square is also called Kai Squared. Chi Square is one of non-parametric comparative tests performed on two variables, in which the scale of data for both variables is nominal (If 1 of 2 variables has a nominal scale, then a chi square test is carried out by referring to the lowest degree). The basis of decision making in the chi square test can be done by looking at the output value of the "Chi Square Test". In decision making, we should consider two things, namely comparing the value of Asymp. Sig with a critical limit of 0.05 or comparing the value of chi-square count with chi square table. Below is the Chi-Square correlation equation:

$$
X_{p}^{2}=\sum_{i j} \frac{\left(f_{i j}-E_{i j}\right)^{2}}{E_{i j}}
$$

1) Considering the value of Asymp. Sig:

- If the value of Asymp. Sig<0.05, then there is a significant relationship between rows and columns

- If the value of Asymp. Sig $>0.05$, then there is no significant relationship between rows and columns.

2) Considering the value of Chi Square:

- If the value of Chi Square Count>Chi Square Table, then there is a relationship between rows and columns.

- If the value of Chi Square Count $<$ Chi Square Table, then there is no relationship between rows and columns.

\section{Spatial Autocorrelation}

Spatial autocorrelation is an estimation of the correlation between the observation values related to the spatial location of the same variable. Positive spatial autocorrelation shows the similarity of values from adjacent locations and tends to be grouped. While negative spatial autocorrelation indicates that adjacent locations have different values and tend to[14]. 


\section{E. Morans'I}

The coefficient of Moran's I is a development of Pearson correlation on univariate series data. The coefficient of Moran's I is used to test spatial dependencies or autocorrelation between observations or locations. The hypothesis used are:

H0: $\mathrm{I}=0$ (there is no autocorrelation among locations)

$\mathrm{H} 1: \mathrm{I} \neq 0$ (there is autocorrelation among locations)

A test statistic (Lee dan Wong, 2001)

$$
Z_{\text {count }}=\frac{I-I_{0}}{\sqrt{\operatorname{var}(I)}} \sim N(0,1)
$$

In which the value of Moran's I is:

$$
I=\frac{n}{\sum_{i=1}^{n} \sum_{j=1}^{n} W_{i j}} \frac{\sum_{i=1}^{n} \sum_{j=1}^{n} W_{i j}\left(x_{i}-\bar{x}\right)\left(x_{j}-\bar{x}\right)}{\sum_{i=1}^{n}\left(x_{i}-\bar{x}\right)^{2}}
$$

Note:

$$
\begin{array}{ll}
x_{i} & =\text { location variable data no-i }(\mathrm{i}=1,2, \ldots, \mathrm{n}) \\
x_{i} & =\text { location variable data no-j }(\mathrm{j}=1,2, \ldots, \mathrm{n}) \\
\bar{x}^{-} & =\text {average data } \\
\mathrm{W} & =\text { weighting matrix } \\
\operatorname{var}(I)= & \text { variant of Moran's I } \\
\underline{E}(I)=\text { expected value of Moran's I }
\end{array}
$$

Ho is rejected or there is autocorrelation among locations if $\left|Z_{\text {count }}\right|>Z_{\alpha / 2}$. The value of index $\mathrm{I}$ is between -1 and 1 . If $I>$ Io, the data has positive autocorrelation. If $\mathrm{I}<\mathrm{Io}$, the data has negative autocorrelation. The pattern of grouping and spreading among locations can be presented using Moran's Scatterplot which can be seen in Figure 2.4 showing the relationship between the observation value in a location and the average observation value of neighboring locations[15]. The scatterplot consists of four quadrants[16], namely:

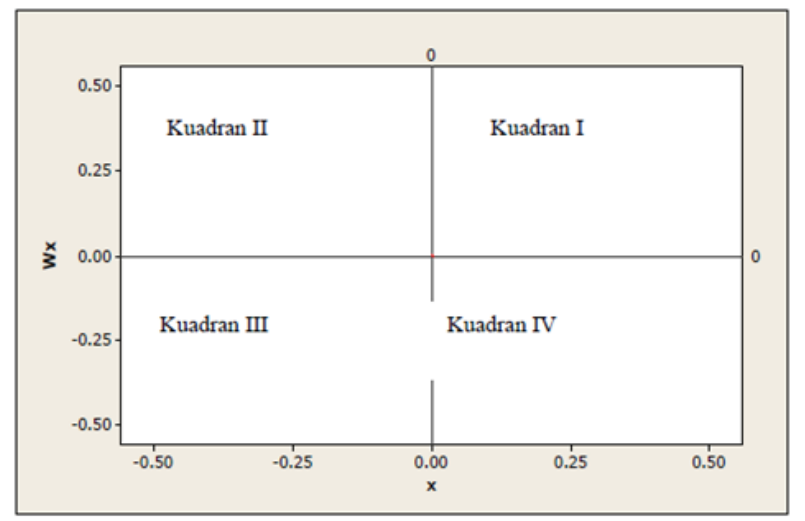

Figure 1. Moran's Scatterplot

- Quadrant I (High-High), indicates a location with high observation values surrounded by a location with high observation values.

- Quadrant II (Low-High), indicates a location with low observation values surrounded by a location with high observation values.
- Quadrant III (Low-Low), indicates a location with low observation values surrounded by a location with low observation values.

Quadrant IV (High-Low), indicates a location with high observation values surrounded by a location with low observation value.

\section{METHOD}

\section{A. Problem Identification Stage}

The purpose of this study was to analyze factors causing customers' late payment. This study used 8 variables consisting of 7 independent variables and 1 dependent variable. The measured variables are:

1) Address $\left(H_{1}\right)$ : customer address taken based on villages.

2) Customer Type $\left(\mathrm{H}_{2}\right)$ : customer class type based on 3 clusters (residential, premium cluster, and official residence/Indonesian National Army/Republic of Indonesia Police).

3) Educational Level $\left(\mathrm{H}_{3}\right)$ : customer education based on education level category that has been determined according to Surabaya area.

4) Total Income $\left(H_{4}\right)$ : customer income based on the category of total income on Surabaya area.

5) Employment Status $\left(H_{5}\right)$ : customer employment status based on employment category in Surabaya area.

6) Payment Period $\left(\mathrm{H}_{6}\right)$ : payment period of customer based on payment term categories every month.

7) Subscription package $\left(H_{7}\right)$ : the type of subscription package product that is used by customer.

8) Payment Status/Late Payment: the total of customer late payments in 1 year

Analysis of customer distribution was carried out in Surabaya area using spatial autocorrelation with the Moran's I method to find out the existence of autocorrelation between location observations and Local Indicator of Spatial Autocorrelation (LISA) to identify how the observation locations relate to other observation locations (dependencies) and using ARCGIS to make a mapping.

\section{B. Data Collection and Data Processing Stage}

\section{1) Data Collection}

Data collection methods used in this study are primary data and secondary data. Primary data is in the form of information obtained through interviews and surveys. While secondary data is in the form of customer payment data for the last year of February 2018-February 2019 period, literatures and reports related to the research object. Data processing techniques would be carried out in 2 ways, namely quantitative data processing (statistical tests) using SPSS and Microsoft Excel tools and descriptive statistic data processing using interpretation of hypothesis test. Surabaya region mapping data was generated from data digitizing that showed an object on the earth surface using 
the ArcGIS 10.3 application to do coloring of each field in Surabaya therefore locations could be distinguished.

2) Data Processing

The Chi-Square correlation analysis was done using Crosstab facilities in SPSS tool. The Chi-Square test aimed to determine the relationship between variables in rows and columns. The usefulness of chi square is to test how well it matches the observed frequency with the expected frequency based on the distribution to be hypothesized. In the process of processing correlation data, there are three interpretations of the results of correlation analysis, including:

1. Interpreting the strength of the relationship between two variables is done by looking at the number of coefficient results calculated;

2. Seeing the significance of the relationship of two variables based on the number of significance generated from the calculation to prove whether the relationship between the two variables is significant or not;

3. See the direction of the rejection area. After that, to test the weighting matrix dependencies used for the spatial autocorrelation test is Queen Contiguity because it represents the intersection of the sides and angles.

Table 1 shows the distribution of customers based on address, customer type, education level, total income, employment status, payment period, and subscription packages variables. The analysis of 400 valid customers shows that the total status of customers who never did late payment are 108 people (27\%), while the number of customers who did late payment are 292 people $(73 \%)$.

Customer distribution both that did late and timely payment based on hypothesis variables showed that the lower the level of education, the total income, and the employment status, the frequency of customers is less and has a tendency to experience late payment. This can be seen that the customer with income $<2 \mathrm{M}$ and student. Whereas analysis based on address, customer type, payment period, and subscription package cannot be used as a reference of payment analysis tendency because it should be done multilevel analysis.

The autocorrelation test results then form Moran's scatterplot. Moran's scatterplot is used to determine patterns of distribution between locations. status tends to experience late payment than others. Then, determine how the characteristics of customers are related between regions and around the area which can be shown using the LISA cluster map. The global spatial autocorrelation in this case is that the Moran's I index does not provide information on spatial patterns in certain regions. Therefore, information on the tendency for spatial relationships is needed in each location by determining LISA (dependencies).

\section{RESULTS AND DISCUSSION}

\section{A. Descriptive Analysis of Research}

The summary of descriptive analysis result on the 8 variables is shown in Table 1 as follows:

TABLE 1.

COMPARISON OF CUSTOMER RESEARCH DATA FREQUENCY DESCRIPTIONS

\begin{tabular}{|c|c|c|c|c|c|c|}
\hline \multirow{2}{*}{ Variable } & \multirow{2}{*}{ Training Data Set } & \multicolumn{4}{|c|}{ Payment Status } & \multirow{2}{*}{ Total of Frequency } \\
\hline & & On Time & Total & Late & Total & \\
\hline \multirow{5}{*}{ Address } & West Surabaya & $36.36 \%$ & 12 & $63.64 \%$ & 21 & 33 \\
\hline & Central Surabaya & $34.00 \%$ & 17 & $66.00 \%$ & 33 & 50 \\
\hline & South Surabaya & $19.74 \%$ & 30 & $80.26 \%$ & 122 & 152 \\
\hline & East Surabaya & $29.17 \%$ & 42 & $70.83 \%$ & 102 & 144 \\
\hline & North Surabaya & $33.33 \%$ & 7 & $66.76 \%$ & 14 & 21 \\
\hline \multirow{3}{*}{ Customer Type } & Residential & $25.31 \%$ & 62 & $74.69 \%$ & 183 & 245 \\
\hline & Official Resident/Indonesian national Army/Police & $35.71 \%$ & 25 & $64.29 \%$ & 45 & 70 \\
\hline & Prime Cluster & $24.71 \%$ & 21 & $75.29 \%$ & 64 & 85 \\
\hline \multirow{3}{*}{ Educational Level } & Bachelor/Diploma & $28.42 \%$ & 79 & $71.58 \%$ & 199 & 278 \\
\hline & Elementary-Junior School/Equal & $27.78 \%$ & 5 & $72.22 \%$ & 13 & 18 \\
\hline & High School/Vacational/Equal & $23.08 \%$ & 24 & $76.92 \%$ & 80 & 104 \\
\hline \multirow{4}{*}{ Total Income } & $<2 \mathrm{M}$ & $9.09 \%$ & 1 & $90.91 \%$ & 10 & 11 \\
\hline & $>5 \mathrm{M}$ & $34.67 \%$ & 52 & $65.33 \%$ & 98 & 182 \\
\hline & $2 \mathrm{M}-3 \mathrm{M}$ & $22.53 \%$ & 41 & $77.47 \%$ & 141 & 57 \\
\hline & $4 \mathrm{M}-5 \mathrm{M}$ & $24.56 \%$ & 14 & $75.44 \%$ & 43 & 150 \\
\hline \multirow{4}{*}{ Employment Status } & Student & $19.67 \%$ & 12 & $80.33 \%$ & 49 & 17 \\
\hline & Civil Servant & $40.00 \%$ & 32 & $60.00 \%$ & 48 & 80 \\
\hline & Private Employee & $24.79 \%$ & 60 & $75.21 \%$ & 182 & 245 \\
\hline & Enterpreneur & $2353 \%$ & 4 & $76.47 \%$ & 13 & 61 \\
\hline \multirow{3}{*}{ Payment Period } & $>$ The 30th & $0.00 \%$ & 0 & $100 \%$ & 28 & 28 \\
\hline & The 1 st -10 th & $39.47 \%$ & 90 & $60.53 \%$ & 138 & 228 \\
\hline & The 11th -20 th & $23.98 \%$ & 16 & $76.02 \%$ & 79 & 95 \\
\hline
\end{tabular}


The $1^{\text {st }}$ International Conference on Business and Management of Technology (IConBMT)

August 3rd 2019, Institut Teknologi Sepuluh Nopember, Surabaya, Indonesia

\begin{tabular}{lcccccc}
\hline & The 21st - 30th & $0.00 \%$ & 0 & $100 \%$ & 49 & 49 \\
\hline \multirow{2}{*}{ Subscription Package } & Telephone + TV + Internet (3P) & $25.54 \%$ & 59 & $74.46 \%$ & 172 & 231 \\
& Telephone/TV + internet (2P) & $28.99 \%$ & 49 & $71.01 \%$ & 120 & 169 \\
\hline \hline
\end{tabular}

TABLE 2.

RESULT OF CHI SQUARE CORRELATION TEST

\begin{tabular}{lcccc}
\hline \hline Variable & X2 count & X2 Tabel (5\%) & df & Description \\
\hline Address & 45.787 & 42.557 & 29 & There is correlation \\
Customer Type & 3.281 & 5.991 & 2 & There is no correlation \\
Educational Level & 1.101 & 5.991 & 2 & There is no correlation \\
Total Income & 8.282 & 7.815 & 3 & There is correlation \\
Employment Status & 9.223 & 7.815 & 3 & There is correlation \\
Payment Period & 46.697 & 7.815 & 3 & There is correlation \\
Payment Status & 0.590 & 3.841 & 1 & There is no correlation \\
\hline \hline
\end{tabular}

Multilevel is other variables for example combined with socio-economic factors (education level, employment status, and income). In addition, data processing was done based on the time of payment (1-year period for 12 months) calculated based on the amount of payment for one year (12 months) with a sample of 400 customers. Therefore, the total payment data is 4,800 transactions (400 customers $\mathrm{x}$ 12 payments). Customers tend to pay after the 20th. In fact, the payment deadline is the 20th of each month.

The conclusion in the descriptive analysis of customer characteristics states that customers tend to do late payment and that it must happen every month. However, late payment occurs at certain times each period (month) only. This happens because the level of expenditure needs in certain months is very high, so for tertiary needs bills will be paid at the end of time.

If the variable has a value of Chi Count>Chi Table then the $\mathrm{H} 0$ was rejected and having correlation with payment status (late payment). Whereas, if the variable has a value of Chi count $<$ Chi Table then the hypothesis fails to reject $\mathrm{HO}$ and it can be said that it has no correlation with the payment status (late payment). The following is an explanation of the results of each variable:

\section{1) Address (H1)}

The value of address chi-count (H1) is higher (45.787>42.557). Walk[17] stated that it was not found a relationship between debt and population in a metropolitan area (city), if it was not done a multi-level analysis. However, based on the research of Simone and Walks[17] correlation could occur if the residence variable was combined with other factors such as social economics (education level, employment status, and total income). Therefore, the address variable had correlation with payment status (late payment).

\section{2) Total Income (H4)}

Value of total income Chi-count (H4) is higher (8.282>7.815). Ellen et. al.[18] stated that income is a variable that is proven to have a positive correlation on customer loyalty of a product. In the payment category model from Financial's point of view by Ellen et al. (2006), the higher the income, the greater the ownership, and its usage intensity. The higher the income the higher the needs, in addition the needs will also increasingly diverse. Therefore, the variable of total income has correlation to late payment.

\section{B. The Interrelation Test Result of Chi-Square Method}

The basis of decision making of correlation coefficients can be done in 2 ways, namely comparing the value of Asymp. Sig. (2 sided) of Chi-Square with the significance level used and comparing the Chi-Square count with ChiSquare tables. If the value of Chi-Square Count> ChiSquare Table, then there is a relationship between the row and the column or hypothesis accepted. The value of $\mathrm{df}$ uses a significance level of $95 \%(\alpha=0.05)$. The following are the results of data processing variables that are suspected to have correlation with late payment (payment status).

3) Employment Status (H5)

Value of employment status Chi-count (H5) is higher (9.223 7.815). Employment status affects the total income. The higher total income, the higher the financial assets, less unsecured debt, and less risks of financial problems[19]. In addition, in Despard's study, the more students have fulltime jobs, the more likely they are to pay their debt debt in a timely manner. Thus, the employment status variable has correlation with late payment.

\section{4) Payment Period (H6)}

Value of employment status Chi count (H6) is greater (46.697> 7.815). In traditional theory, payment term is made to build a smooth corporate cashflow. Thus the company will conduct a forecasting of customer cashflow. Customers with stable cashflow or receiving income within a certain time are easier to manage. While customers with highly volatile cash flows have a risk of being late in conducting transactions[20]. Customers with High Volatile Cash Flows can be caused by an uncertain amount or payment term. Thus, the payment period variable has correlation with late payment. 


\section{5) Customer Type (H2)}

The value of customer type Chi-count (H2) is smaller (3.281 <5.991). Kwanda et. al.[21] stated that the most influental factors of customer satisfaction in choosing a house are location, building quality, infrastructure, utilities and facilities. However, this does not mean that the payment of the prime cluster type will tend to be late. The customer type category must still be processed in multilevel. Thus, the customer type variable has no correlation with late payment.

6) Educational Level (H3)

The value of customer type Chi-count (H2) is smaller (1.101 <5.991). Based on Essael's theory (1987: 11), customer decisions are influenced by three factors, namely: (1) individual customer factors which include education and customer income; (2) environmental influences; and (3) marketing strategies. Education influences customers in making decisions. However, in the study of Mantel[22], it was stated that the level of education was not a statistically significant factor in the pattern of customer payments. Therefore, the education level variable has no correlation with payment status (late payment).

\section{7) Subscription package (H7)}

The value of customer type chi-count (H2) is smaller $(0.590<3.841)$. Based on the journal Ellen et. al. [18], income is a variable that is proven to affect the amount of product usage loyalty with a positive relationship. However, product selection is a factor that cannot be determined for anything because it is subjective as needed or even just because of customer interest. So, the subscription package variable has no relation to late payment.

\section{Analysis of Spatial Autocorrelation and Dependency Test}

The method of analysis through data exploration on thematic maps is continued by analysis of spatial autocorrelation, namely Moran's I and LISA. The weighting used is binary code, the intersection of the angles (Queen Contiguity).

TABLE 3.

MORAN'S I VALUE USING QUEEN MATRIX

\begin{tabular}{ccc}
\hline \hline \multirow{2}{*}{ Variable } & \multicolumn{2}{c}{ Queen Contiguity } \\
\cline { 2 - 3 } & Moran's & Z Count \\
\hline Total income & 0.1328 & 6.43782 \\
Employment status & 0.1033 & 8.63556 \\
\hline \hline
\end{tabular}

The interpretation analysis of the Morans'I test could be done in 2 ways, indicated by the comparison of Z-count $>$ $Z$-table or I $<$ I. Value of Z-table was obtained from the division of $Z_{-}(\propto / 2)$ in which $\propto=$ signifikansi $5 \%, \frac{Z_{0,05}}{2}=$ $Z_{0,025}=1.96$. The result of Moran's I calculation using spatial weighting matrix of Queen Contiguity is presented in the Table 3. In Chi-Square analysis, it is shown that besides address $(\mathrm{H} 1)$, other variables that have significant correlation with late payment are total income $(\mathrm{H} 4)$ and employment status (H5). Therefore, only these two variables that would be analysed its dependency and spatial autocorrelation.

In the Queen Contiguity matrix, Z-count value of total income variable $(\mathrm{H} 4)$ is $6.4378>1.96$. Z-count value of employment status variable (H5) is $8.63556>1.96$. This shows that there is a positive autocorrelation or a clustered pattern and having similar characteristics in adjacent locations. This spatial autocorrelation indicates that there is a relationship or correlation between percentage values of customers in certain villages areas or there are groupings in several locations.

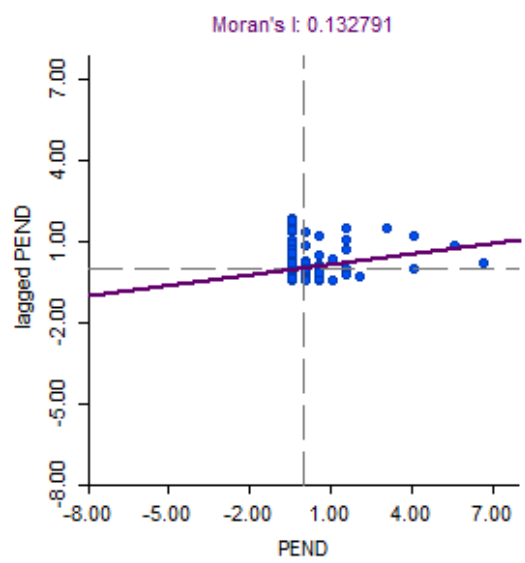

Figure 1. Moran's Scatterplot Value of Queen Matrix of Income Variable

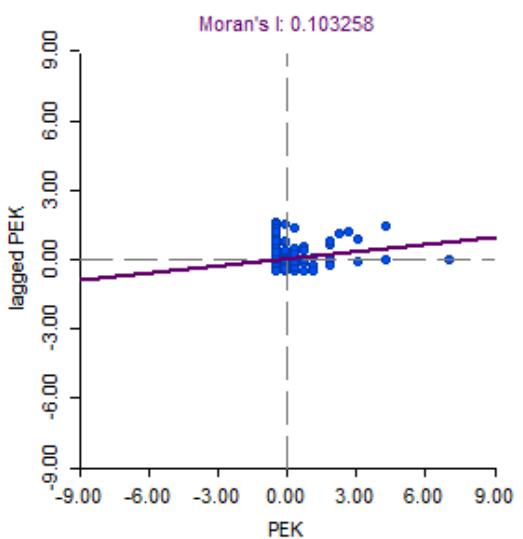

Figure 2. Moran's Scatterplot Value of Queen Matrix of Employment variable

In addition, calculation was done using Moran's Scatterplot to find out and display an explanation of village location in each quadrant. Moran's Scatterplot Value of The Queen Matrix of total income shows the relationship pattern between the distribution of customers income level and employment status towards customer distribution in various village.

From testing with the Moran Index, it was concluded that there was spatial autocorrelation with a 5\% significance level in mapping the distribution of customers in the Surabaya area. With the Moran Index value of 0.1328 on 
the total income variable and 0.1033 on the employement variable the status is in the range 0 and 1 then it can be concluded that the resulting autocorrelation is positive spatial autocorrelation.

Positive autocorrelation indicates that the adjacent location has similar values and the case of the spread of ISP customers tends to be in groups. In the analysis, neighboring conditions are based on the kelurahan, therefore the group in question is between kelurahan one with other kelurahan with groups of almost the same number of customers.

High-High Area (HH) Quadrant 1, indicates an area that has a high observation value surrounded by areas that have a high observation value. Consisting of Darmo Village, Gubeng Village, Ngagel Village, Keputran Village, Siwalankerto Village, and Jambangan Village. Low-High Area (LH) Quadrant II, shows an area that has a low observation value but is surrounded by areas that have high observation values. Consisting of Embong Kaliasin Village, Kelurahan Kejawan Putih Tambak, Dr. Sutomo, Menanggal Village, Kebonsari Village, Jemur Wonosari Village, Ketintang Village, Karah Village, Dukuh Menanggal Village, Jagir Village. Low-Low Area (LL) Quadrant III, indicates an area that has a low observation value surrounded by areas that have a low observation value. Consisting of Asemrowo Village, Greges Village, Buntaran Village, Kandangan Village, Ujung Village, Ampel Village, Sidodadi Village, Tambak Osowilangun Village, Sememi Village. High-Low Area (HL) Quadrant 4, indicates an area that has a high observation value surrounded by areas that have low observation value. Consisting of Lakarsantri Village, Manukan Wetan, Jepara, Dukuh Kupang.

\section{CONCLUSION}

Customer distribution both doing late payment and timely payment based on hypothesis variables shows that the lower the educational level, the total income, and the employment status, the frequency of customers is less and haing a tendency to experience late payment. Whereas analysis based on address, customer type, payment period, and subscription package could not be used as a reference for analyzing payment trends because it must be associated with socio-economic factors. The results of correlation analysis or significant relationship to the late payment variable are variables that have a Chi Square count value greater than the Chi Square Table. The variables that have Chi-count value> Chi-Table value is address, total income, employment status, and payment period. Thus, the four variables above are the null hypothesis 0, that have a significant relationship with the variable payment status/late payment.

The characteristics and distribution patterns of IndiHome a customer in Surabaya to monthly payments is shown by the Morans'I index value. The matrix used is the spatial weighting matrix of Queen Contiguity. This payment distribution pattern is based on variables that have an autocorrelation value in the village area, namely income level and employment status. The Morans'I index value of educational level is 0.1328 and the Morans'I index value of employment status is 0.1033 . This result shows that there is a positive autocorrelation from the value of I0 -1.0025 . In addition, there is a clustered pattern that has similar characteristics in adjacent locations (there are spatial dependencies). The pattern of prominent customer characteristics is grouped in Quadrant III according to the visualization of Moran's Scatterplot and LISA Cluster Map.

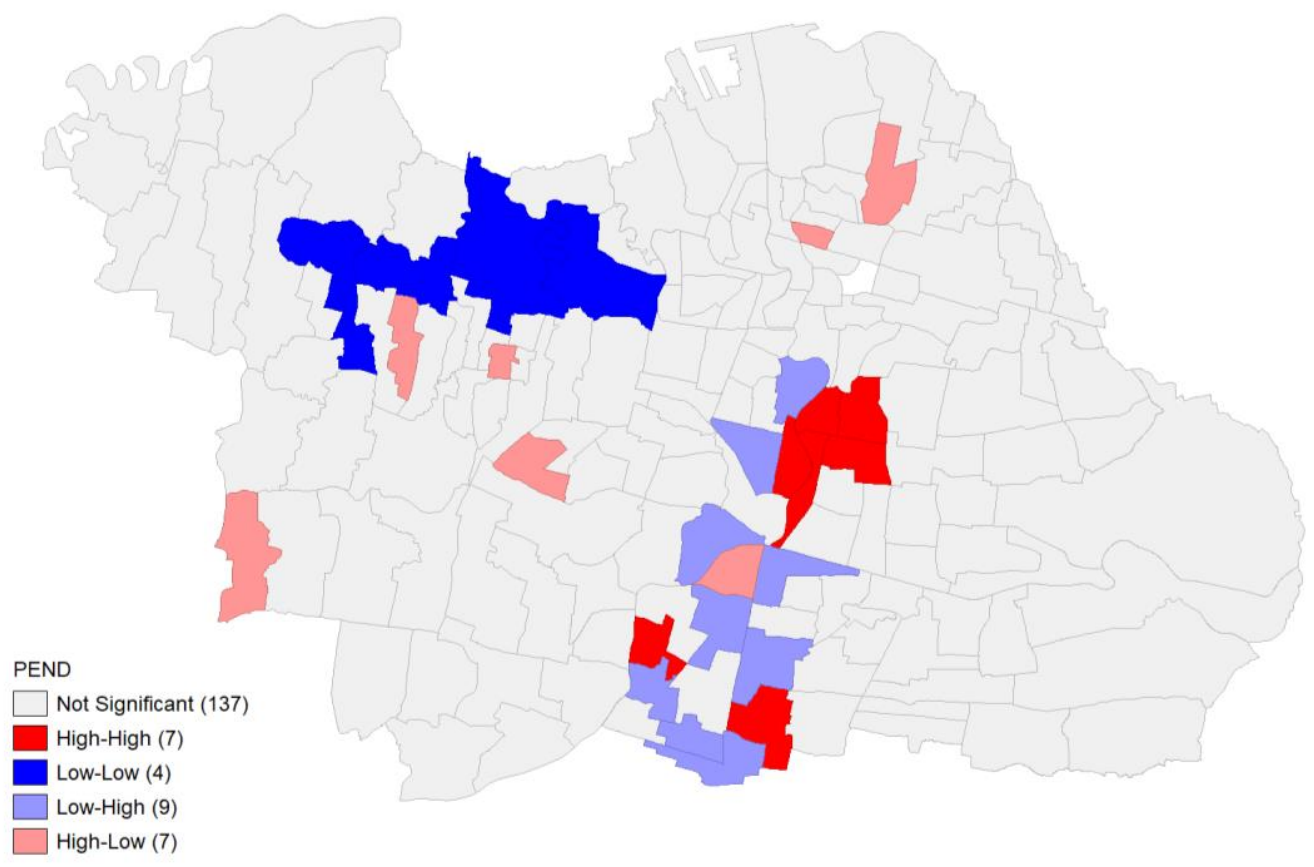




\section{REFERENCES}

[1]

D. E. Kieso, J. J. Weygandt, and T. D. Warfield, Intermediate Accounting, 16a ed. Hoboken, New Jersey: John Wiley \& Sons, 2016.

[2] X. Luo and C. Homburg, "Neglected outcomes of customer satisfaction," J. Mark., vol. 71, no. 2, pp. 133-49, 2007.

[3] M. M. Akbar and N. Parvez, Impact of service quality, trust and customer satisfaction on costumer loyalty, vol. 29, no. 1 . The University, 1993.

[4] T. Wijayanti, "Analisis Faktor-faktor yang Memengaruhi Tunggakan Kredit Usaha Mikro pada Swamitra Koppas Kramat Jati," Institut Pertanian Bogor, 2014.

[5] X.-N. Huo, H. Li, D.-F. Sun, L.-D. Zhou, and B.-G. Li, "Combining geostatistics with Moran's I analysis for mapping soil heavy metals in Beijing, China," Int. J. Environ. Res. Public Health, vol. 9, no. 3, pp. 995-1017, Mar. 2012.

[6] A. Furchan, Pengantar Penelitian dalam Pendidikan. Yogyakarta: Pustaka Pelajar, 2004.

[7] S. Y. Paul, S. S. Devi, and C. G. Teh, "Impact of late payment on Firms' profitability: Empirical evidence from Malaysia," Pacific-Basin Financ. J., vol. 20, no. 5, pp. 777-792, Nov. 2012.

[8] N. Zainudin, "Tracking the credit collection period of Malaysian small and medium-sized enterprises," Int. Bus. Res., vol. 1, no. 1, pp. 78-86, 2008.

[9] J. F. Engel, R. D. Blackwell, and P. W. Miniard, Consumer Behavior, 7th ed. Fort Worth: Dryden Press, 1995.

[10] A. M. Salama, A lifestyle theories approach for affordable housing research in Saudi Arabia, vol. 11, no. 1. 2006.

[11] S. Listyorini, "Analisis faktor - faktor gaya hidup dan pengaruhnya terhadap pembelian rumah sehat sederhana," $J$. Adm. Bisnis, vol. 1, no. 1, Sep. 2012.

[12] M. Nazir, Metode Penelitian. Jakarta: Ghalia Indonesia, 1998.
[13] J. C. Mowen, Perilaku Konsumen. Jakarta: Erlangga, 1995.

[14] R. Kosfeld, "Spatial Econometrics." University of Kassel, Germany, 2006.

[15] J. Lee and D. W. Wong, Statistical Analysis with ArcView GIS. Canada: John Willey \& Sons, Inc, 2001.

[16] F. Perobelli and E. A. Haddad, "Brazilian interregional trade (1985-1996): An exploratory spatial data analysis," in Anais do XXXI Encontro Nacional de Economia [Proceedings of the 31st Brazilian Economics Meeting], 2003.

[17] D. Simone and A. Walks, "Immigration, race, mortgage lending, and the geography of debt in Canada's global cities," Geoforum, vol. 98, pp. 286-299, Jan. 2019.

[18] P. S. Ellen, D. J. Webb, and L. A. Mohr, "Building corporate associations: Consumer attributions for corporate socially responsible programs," J. Acad. Mark. Sci., vol. 34, no. 2, pp. 147-157, Apr. 2006.

[19] M. R. Despard, D. Perantie, S. Taylor, M. Grinstein-Weiss, T. Friedline, and R. Raghavan, "Student debt and hardship: Evidence from a large sample of low- and moderate-income households," Child. Youth Serv. Rev., vol. 70, pp. 8-18, Nov. 2016.

[20] N. Glady, A. Lemmens, and C. Croux, "Unveiling the relationship between the transaction timing, spending and dropout behavior of customers," Int. J. Res. Mark., vol. 32, no. 1, pp. 78-93, Mar. 2015.

[21] J. Rahardjo, B. R. Wibowo, and T. Kwanda, "Analisis kepuasan penghuni rumah sederhana tipe 36 di kawasan Sidoarjo bedasarkan faktor kualitas bangunan, lokasi, desain, sarana dan prasarana," Dimens. Tek. Arsit., vol. 31, no. 2, pp. 124-132, 2003.

[22] B. Mantel, "Why do consumers pay bills electronically? an empirical analysis," Econ. Perspect., no. Q IV, pp. 32-48, 2000. 